\title{
Assessment of Groundwater Quality Properties in a University Sub-Urban Community in Delta State, Nigeria: Part B-Correlation Analysis and Household Water Treatment Adoption
}

\author{
OWAMAH, HI \\ Department of Civil Engineering, Faculty of Engineering, Delta State University, PMB1, Abraka, Oleh Campus, Delta State, Nigeria \\ Email: owamah.hilary@gmail.com; hiowamah@delsu.edu.ng; Tel: +2348035705814
}

\begin{abstract}
In this paper, the correlation analysis of the physical and chemical properties of bore-holes (BHs) and hand-dug wells (HDWs) water samples monitored in Oleh, Delta State, is reported. Households were also interviewed to evaluate level of access to clean water, quality of water and knowledge of water treatment. The correlation analysis showed that the major cations and anions contributing to TDS are $\mathrm{Na}(0.92), \mathrm{Mg}(0.85), \mathrm{Ca}(0.83), \mathrm{K}(0.77)$, and $\mathrm{SO}_{4}{ }^{2-}$ (0.89) and $\mathrm{Cl}^{-}(0.88)$ respectively. Chloride ion $\left(\mathrm{Cl}^{-}\right)$was also found to be linked to Na-Mg group with perfect correlations (0.92-0.90). While $\mathrm{Pb}$ and $\mathrm{Cd}$ had very strong correlations with the anions, $\mathrm{SO}_{4}{ }^{2-}$ also correlated well with $\mathrm{Ba}, \mathrm{Na}, \mathrm{K}$ and $\mathrm{Mg}$. Total coliform bacteria was found higher in HDWs indicating that boreholes in the community were safer sources drinking water. About $(<32 \%)$ of the households surveyed accessed water from HDWs and never practiced any form of household water treatment. Majority of the HDW water samples $(72 \%)$ fell within the class of "low risk $(\mathrm{FC},>11-100 \mathrm{cfu} / 100 \mathrm{~mL})$. The study recommends regular monitoring of study area groundwater and the provision pipeborne water.
\end{abstract}

\section{DOI: https://dx.doi.org/10.4314/jasem.v23i3.16}

Copyright: Copyright (C) 2019 Owamah. This is an open access article distributed under the Creative Commons Attribution License (CCL), which permits unrestricted use, distribution, and reproduction in any medium, provided the original work is properly cited.

Dates: Received: 01 January 2019; Revised: 21 February 2019; Accepted 12 March 2019

Keywords: Groundwater, quality, public health, pollution

The essentiality of water for the protection and or provision of public health, food security, and environmental sustainability cannot be overemphasized (Sojobi, 2016; Owamah et al., 2013). Groundwater is however the main water source for domestic and sometimes industrial uses in Nigeria. These are often abstracted through boreholes and shallow wells and used directly, without any form of quality testing or treatment. It is generally believed by rural dwellers that groundwater is clean and poses no threat to human health (Masoud et al., 2018). The pollution of groundwater amounts to loss of usable water resources with an opportunity cost. This combination of direct usage of groundwater and lack of household water treatment in virtually all Nigerian rural and sub-urban communities could be one of the impending greatest public health challenges facing the country. Studies directed at improving awareness of policy makers and the public on the worth of groundwater, the public health implication of getting it polluted, the financial cost of remediation and methods etc. are urgently needed. Over 3.4 billion persons living in developing nations have been estimated to be highly vulnerable to water-borne diseases and water insecurity (Vorosmarty et al., 2010). This malady has however been overcome in developed nation and has thus redefined their research interest in water matters (Sojobi, 2016).

The Nigerian governments at all levels have not been over the years, able to provide improved water to her citizens. This has directly or indirectly resulted in socio-economic, health, environmental and other challenges. It has also been reported to be among the causes of high rate of premature mortality and morbidity in many Nigerian states (Sojobi, 2016). Some of the reasons advanced for the inability of governments in Sub-Saharan Africa to provide improved water for their citizens are inadequate infrastructure, lack of innovative ideas, huge population, bad maintenance culture, inadequate power, lack of political commitments and corruption (Sojobi, 2016). According to the World Bank Report of 2011, closing the infrastructural deficit gap in SubSahara Africa (SSA) would require about ninetythree billion dollars (World Bank, 2011) which will amount to infrastructural investment of \$1.2-1.5 billion every year for the provision of basic amenities like improved drinking water, energy, and good roads etc. (Fay et al., 2010). The objective of this study was to run the correlation analysis of the physicochemical properties of boreholes (BHs) and hand-drawn wells (HDWs) in Oleh, Delta State. 


\section{MATERIALS AND METHOD}

Description of study area: This research was carried out in Oleh with coordinates of latitude $5^{\circ} 27^{\prime} 32.17^{\prime \prime} \mathrm{N}$ (latitude) and $6^{\circ} 12^{\prime} 11.13^{\prime \prime E}$ (longitude) and presently, the headquarters of Isoko South Local Government Area (ISLGA) of Delta State. Oleh is not only the most populated community in ISLGA, major economic activities in the Local Government Area also take place in the community. The map of ISLGA showing Oleh is shown in Fig. 1. ISLGA is situated in the tropical rainforest region and experiences rainy and harmattan seasons.

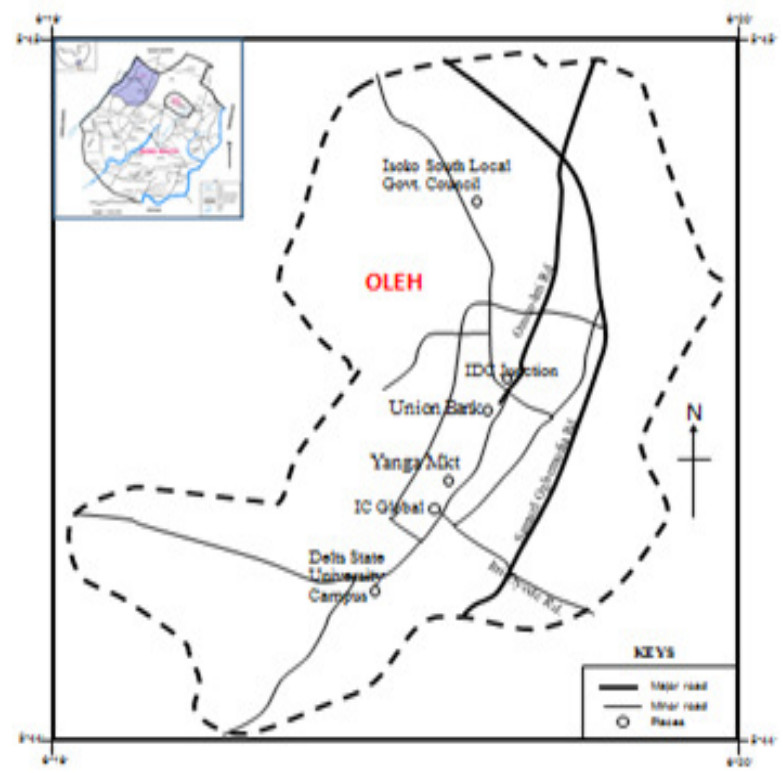

Fig. 1: map of study area: Source: Ministry of LANDS, Survey and Urban Development, Asaba 2018

Oleh houses the Law and Engineering Faculties of the Delta State University, Nigeria. While the ISLGA is a main crude oil producing zone in Nigeria, its headquarters (Oleh), jointly houses a flow station with nearby Olomoro community.

Collection of water sample: High-density PET bottles (1.5 L size) were used for the collection of water samples from the bore-holes and hand-drawn wells from the $1^{\text {st }}$ of June 01, 2016 through January 31, 2017. Actual samples were only collected after the PET containers and stoppers had been washed thoroughly with distilled water and the water to be sampled. The bottles were thereafter, stopper and sent to the laboratory for physicochemical and microbial analyses. For all the sampling points, following Shakerkhatibi et al. (2019), while some containers were filled with water having no acid, others were acidified with few drops of $5 \% \mathrm{HNO}_{3}$ to stop the activities of microorganisms.
Collection of water samples for microbial evaluation was done using autoclave-sterilized containers. For the sake of collection and reporting convenience, the whole of Oleh community was grouped into six districts [Old Emede Road (OER), Engineering Faculty (EF), Yanga market (YM), Itofu (IT), Faculty of Law (FL) and the Government Residential Area (GRA) districts]. A sum total of hundred and eight (108) water samples were collected all-together.

Analytical procedures: Temperature, $\mathrm{pH}$, electrical conductivity and salinity were analyzed in-situ using handy digital equipment listed in Owamah et al. (2013).Following APHA (1992), dissolved oxygen and Chloride contents were measured using the azide modification of Winkler's and the titration methods respectively. Using the UV spectrophotometer (DR 2800) and adopting UV spectrophotometer screening technique, the concentration of the anions were measured following the established protocol in APHA (2012). Reliability and reproducibility of results was ensured through analyzing after every 10 samples, pre-analyzed, standard and blank samples (Dahunsi et al., 2014). Standard methods were adopted to count the total coliform bacteria (Owamah et al., 2013). Following the guidelines in APHA (2012), atomic absorption spectrophotometer (Sens AA 3000) was used for the analyses of the metals.

Disease, Water Quality Perception and House Treatment Level Survey: For clearer evaluation of the possible implications of drinking contaminated water on the health of residents, a disease survey was done using structured questionnaires. The questionnaires also contained information relating to the perception of the residents about the quality of their drinking water sources and level of household water treatment. The survey team comprised four (4) experts on environmental health and eight (8) undergraduate students of environmental engineering. Before the beginning of the survey, the consents of respondents were sought. Selection of respondents from the community was randomly done. One thousand (1000) respondents, comprising both genders, with a minimum of primary school education, were captured in the disease survey. For perception and household water treatment, 200 households comprising a minimum of 3 inhabitants were surveyed. The questionnaires captured occupational data, demographic data, and habits of the respondents. Difficult terminologies in the questionnaire were explained to respondents by members of the survey team.

Statistical analyses: The 2010 veriosn of Microsoft Office Excel was used for the statistical analyses of 
data obtained. The Analysis of Variance (ANOVA) was also employed at 5\% significant level for further interpretation of data obtained.

\section{RESULTS AND DISCUSSION}

Correlation analyses: Comprehensive data obtained for the physiochemical properties of the groundwater had been presented and documented in the Part A of this paper. The focus of this part B is on the correlation analysis of data obtained, determination of household level of water treatment in the community and the establishment of a possible relationship between water-borne diseases observed in the study and contaminants revealed by the study. Table 1shows the correlation coefficient values of main ground water parameters investigated for Oleh community. Table 1 indicates that the major cations and anions contributing to TDS are $\mathrm{Na}(0.92), \mathrm{Mg}$ (0.85), $\mathrm{Ca}(0.83), \mathrm{K}(0.77)$, and $\mathrm{SO}_{4}{ }^{2-}(0.89)$ and $\mathrm{Cl}^{-}$ (0.88) respectively. This result is similar to the one obtained by Sojobi (2016) that Calcium is an parameter for estimating the total dissolved solids in groundwater. It further shows that for the groundwater of the study area, the two most important cation and anion for predicting TDS are respectively, $\mathrm{Na}(0.92)$ and $\mathrm{SO}_{4}^{2-}(0.89)$.

Table 1: Correlation of major parameters investigated

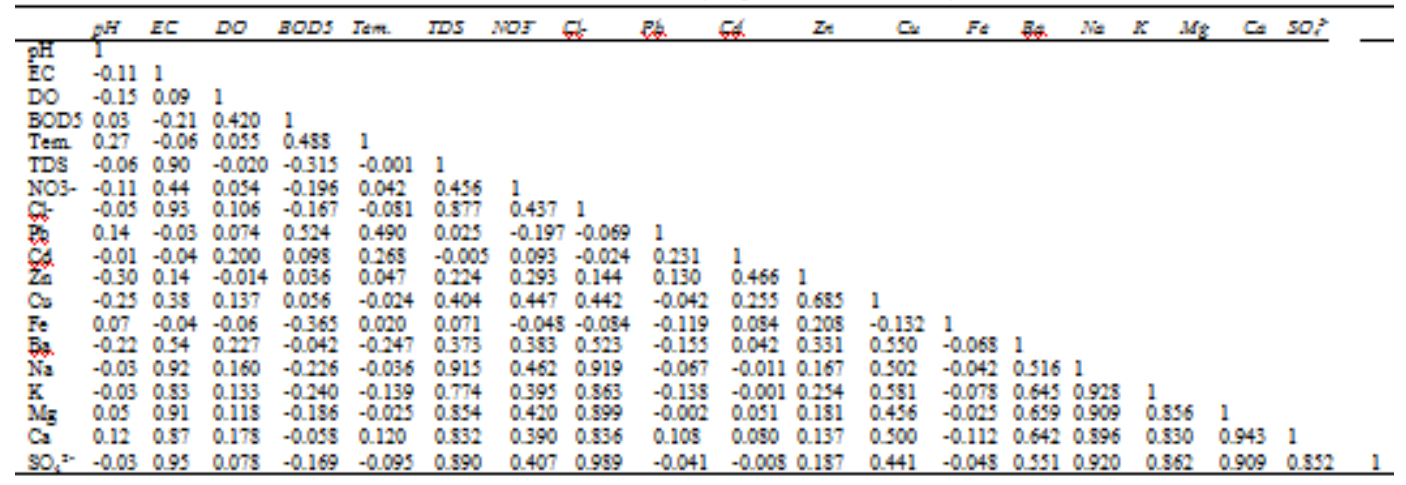

Correlation categories adopted for this research are: perfect $\left(R^{2}=1\right)$, very strong $\left( \pm 0.9 \leq R^{2} \leq 1\right)$, strong ( $\left.\pm 0.7 \leq R^{2}< \pm 0.9\right)$, moderate $\left( \pm 0.5 \leq R^{2}< \pm 0.9\right)$, and poor $\left(R^{2}< \pm 0.5\right)$ (Sojobi, 2016)

Chloride ion $\left(\mathrm{Cl}^{-}\right)$was found to be linked to $\mathrm{Na}-\mathrm{Mg}$ group with perfect correlations $(0.92-0.90) . \mathrm{Pb}$ and $\mathrm{Cd}$ had very strong correlations with the anions studied (Table 1). $\mathrm{SO}_{4}{ }^{2-}$ correlated well with $\mathrm{Ba}, \mathrm{Na}$, $\mathrm{K}$ and $\mathrm{Mg}$ (Table 1). The perfect positive correlation between $\mathrm{SO}_{4}{ }^{2-}$ and $\mathrm{Na}$ of 0.92 suggests a strong dependence on each other and possible similar anthropogenic sources (Sojobi, 2016). Similarly, Mg and $\mathrm{SO}_{4}{ }^{2-}$ were noted to be perfectly correlated $(0.91)$ too and could be linked to both coming from the same anthropogenic sources like domestic wastewaters. $\mathrm{NO}_{3}^{-}$, generally, had poor correlation performance with all the cations showing that its presence in the groundwater could be more of natural causes. Table 1 shows that the chloride and $\mathrm{SO}_{4}{ }^{2}$ ions affinity for the metals is in the order of $\mathrm{Na}>$ $\mathrm{Mg}>\mathrm{K}>\mathrm{Ca}$. The preference of magnesium even in dissolved form by anions in aquifers is usually low (Sojobi, 2016) and could have resulted in the high concentration of magnesium in the community groundwater. These findings suggest prevalence of halite and sodium-rich carbonate minerals in the groundwater (Sojobi, 2016). The EC was found to be weakly correlated with DO (0.09), $\mathrm{NO}_{3}{ }^{-}(0.447418)$, $\mathrm{Fe}(-0.04)$, $\mathrm{pH}(-0.11)$, and $\mathrm{BOD}_{5}(-0.22)$. Findings from this study imply that dissolved oxygen, $\mathrm{NO}_{3}^{-}$,
Iron, Calcium, $\mathrm{pH}$, and $\mathrm{BOD}_{5}$ cannot be conveniently used as predictors for electrical conductivity in the area of study.

Microbiological analysis of the groundwater: Table 2 reveals the average values of total coliform bacteria from the HDW and $\mathrm{BH}$ water samples. Among the 6 districts, the LF borehole water sample of both seasons had the least total coliform (TC) bacteria. For rainy and hamattan seasons, TC count per $100 \mathrm{~mL}$ sample showed respectively, average seasonal values of 5 and 3 . The range was 1 to 6 and 1 to 5 per 100 $\mathrm{mL}$ in the rainy and hamattan seasons respectively. Generally, values obtained in the rainy season were found to be higher than those obtained in the hamattan season and could be linked to poor waste management. Hand-drawn well water samples also had higher values than boreholes. Owamah et al. (2013) obtained similar findings for neighboring communities.

ANOVA showed that there was significant ( $\mathrm{p}<$ $0.005)$ variation among the samples of $\mathrm{BHs}$ and HDWs across the 6 districts. The highest value of 6 was found in the HDW sample from YM district in the month of July. SON (2007) and WHO (2006) 
standards (Table 2) give 10 and 0 count per $100 \mathrm{~mL}$ respectively.

Table 2. Number of coliform bacteria (MPN $100 \mathrm{~m} \mathrm{~L}^{-1}$ ) in groundwater samples for wet and dry seasons $(\mathrm{N}=18)$

\begin{tabular}{|c|c|}
\hline Location & Total coliform \\
\hline${ }^{\mathrm{w}} \mathrm{OER}, \mathrm{BH}$ & $2.10 \pm 0.9$ \\
\hline${ }^{\text {wOER,HDW }}$ & 5. $01 \pm 2.2$ \\
\hline d OER ,BH & $\mathrm{ND}^{\mathrm{a}}$ \\
\hline dOER, HDW & $4.03 \pm 0.3$ \\
\hline w $\mathrm{OEF}, \mathrm{BH}$ & $\mathrm{ND}^{\mathrm{a}}$ \\
\hline${ }^{w} E F, H D W$ & $1.12 \pm 0.6$ \\
\hline${ }^{\mathrm{d}} \mathrm{EF}, \mathrm{BH}$ & $1.01 \pm 0.5$ \\
\hline${ }^{\mathrm{d}} \mathrm{EF}, \mathrm{HDW}$ & $5.04 \pm 0.9$ \\
\hline${ }^{\mathrm{w}} \mathrm{YM}, \mathrm{BH}$ & $4.02 \pm 2.1$ \\
\hline "YM, HDW & $6.01 \pm 2.6$ \\
\hline dYM, BH & $2.09 \pm 1.3$ \\
\hline${ }^{\mathrm{d}} \mathrm{YM}, \mathrm{HDW}$ & $2.05 \pm 0.4$ \\
\hline w IT,BH & $\mathrm{ND}^{\mathrm{a}}$ \\
\hline${ }^{\mathrm{w}} \mathrm{IT}, \mathrm{HDW}$ & $2.04 \pm 0.6$ \\
\hline${ }^{\mathrm{d}} \mathrm{IT}, \mathrm{BH}$ & $1.42 \pm 0.4$ \\
\hline${ }^{\mathrm{d}} \mathrm{IT}, \mathrm{HDW}$ & $3.83 \pm 1.6$ \\
\hline wLF, BH & $1.41 \pm 0.9$ \\
\hline${ }^{\mathrm{w}} \mathrm{LF}, \mathrm{HDW}$ & $2.02 \pm 1.7$ \\
\hline${ }^{\mathrm{d}} \mathrm{LF}, \mathrm{BH}$ & $3.04 \pm 2.1$ \\
\hline${ }^{\mathrm{d}} \mathrm{LF}, \mathrm{HDW}$ & $3.02 \pm 0.8$ \\
\hline${ }^{\mathrm{w}} \mathrm{GRA}, \mathrm{BH}$ & $2.01 \pm 0.5$ \\
\hline${ }^{\mathrm{w}}$ GRA, HDW & $\mathrm{ND}^{\mathrm{a}}$ \\
\hline${ }^{\mathrm{d}} \mathrm{GRA}, \mathrm{BH}$ & $1.10 \pm 0.9$ \\
\hline dGRA, HDW & $3.12 \pm 0.8$ \\
\hline
\end{tabular}

Mean \pm standard deviation; ${ }^{w \& d}=$ wet \& dry seasons; $N D=$ Not detected

This implies that by the WHO (2006) specification, drinking water from $\mathrm{BHs}$ and HDWs in the area of study are coliform bacteria contaminated. The higher values in OER district and YM district could have resulted from its higher population because of the presence of the students of Delta State University, Oleh Campus, clustered around the area and the huge economic activities in the YM district. The presence of coliform in the majority of the samples collected could be because a large number of persons that use pit latrines and obtaining water from shallow wells. It can also be linked to open defecation and runoff, which still take place in the community.

The close proximity of wells to local toilets and septic tanks cannot also be ruled out as part of the cause. The presence of coliform bacteria in the groundwater suggests the existence of pathogenic organisms which can lead to intestinal disorders, cholera, hepatitis, etc. (Mkwate et al., 2017). Physical observation in the course of the study revealed the presence of pit latrines sited and built close $(<20 \mathrm{~m})$ to water wells. The depth $(5-8 \mathrm{~m})$ at which water is tapped from most hand-drawn wells was also noted to be shallow. Enterobacter aerogenes and E. coli. were the microorganisms found in the BH and HDW samples. As reported by Mackie et al. (2006), the presence of these organisms in the $\mathrm{BH}$ and HDW water samples shows that these wells may have been polluted with feces of humans and or animal. Owamah et al.(2013) had earlier reported about boreholes and shallow wells in selected towns in South-Western Nigeria of being contaminated by Enterobacter aerogenes and E. coli.

This is usually the case for communities, littered with droppings as reported by Agbabiaka and Sule (2010). BHs and HDWs in the area of study are surrounded with littered droppings of goats and poultry. Some of the wells are also close to poorly constructed septic tanks. Open defecation is common too owing to the absence of modern sanitary systems in some homes and public places. Jacinta and Adebayo (2015) had earlier reported the presence of $E$. aerogenes and $E$. coli in water samples from HDWs and BHs in Gwagwalada, Abuja, Nigeria.

Illnesses such as cough, fever, headache, diarrhea etc. could be caused by E. aerogenes (Sojobi, 2016). Although Mackie et al. (2006) claimed that $E$. aerogenes was non-pathogenic; they have been reported to be of significant health risk to humans due to their resistance to common antibiotics (Sojobi, 2016). This study has revealed poor sanitation and poor waste management practices in the community. It is therefore recommended that emphasis be placed on household sanitation practices and safe water abstraction. Majority of samples from HDWs and BHs $(78 \%)$ fell into the category of "low risk" with FC counts of below 11-100 cfu/100 mL (Mkwate et al, 2017) and shows groundwater in the area of study especially the ones tapped through hand-drawn wells, need treatment prior to consumption. This could be by simple boiling, chlorination etc.

Household treatment and storage of drinking water: Water can be treated at home by boiling, chlorination, solar disinfection etc. (Mwabi et al., 2012). Most households surveyed in study area ( $>80$ $\%$ ) have never practiced any form of household water treatment. Also (>52\%) of the households, agreed to not having any knowledge of household water treatment. This calls for urgent attention to forestall future outbreaks of major water borne diseases in the community.

From Fig. 2, the majority of the households (67\%) agreed they use plastic drums to store their drinking water. While thirty-two (32\%) said they do not store water but only fetch and use when needed, (10\%) claimed they use jerry cans. A large number of households in the area were found not to be well informed about benefits of household water treatment. 


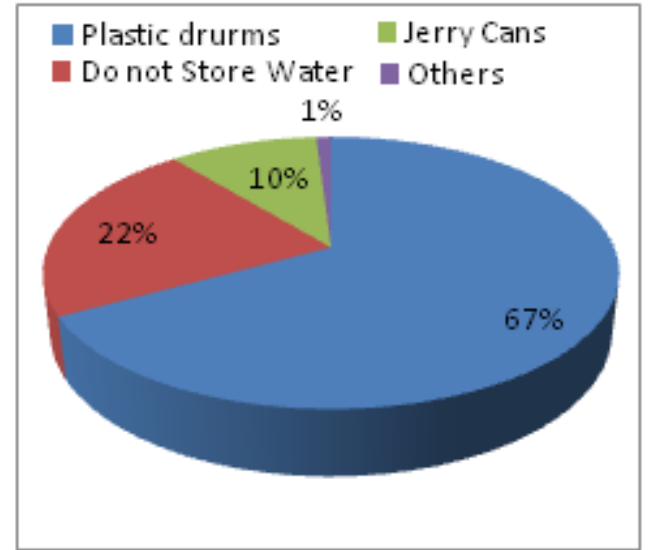

Fig 2: Percentage distribution of households $(n=108)$ by water storage

Drinking water quality perception in the area of study: The common sources of drinking water for the majority of households in the area of study were found to be boreholes $(>65 \%)$, hand-drawn $(<32 \%)$ and others $(<3 \%)$. It was observed from the study that only households that could not afford having boreholes, resorted to HDWs and streams, health implications notwithstanding. Surprisingly, with regards to the perception of residents towards the quality of their drinking water sources, less than $50 \%$ of the respondents expressed concern about the safety of their drinking water sources showing that the residents either believe that their groundwater is safe or do not accord enough priority to knowing the quality status of their drinking water. This calls for massive public awareness programmes to avert the possibility of any water-borne disease outbreak. This finding is somewhat different from that of Mkwate et al. (2017) for Balaka District of Malawi, in which a large number of respondents (73\%) were not satisfied with the odour and clarity of water from HDWs and considered them, potential sources for waterborne diseases. The differences in the response rates can be linked to the different level of water quality awareness in the area of study and Balaka, Malawi. Almost all the households (>95\%) who owned boreholes however expressed satisfaction in the quality and safety of their drinking water even when little or no prior test has been carried out since the installation of the boreholes.

Health Challenges: Table 3 shows the summarized report of the health challenges obtained from the questionnaire survey. Cholera, diarrhea, gastroenteritis, typhoid and dysentery were reported by $22 \%, 16 \%, 38 \%, 40 \%$ and $21 \%$ of the respondents, respectively. These are common water borne diseases known to be associated with bacterial contamination of water (Owamah et al., 2013) and hence corroborate the microbiological parameters findings of this study. Ten (10), 7, and $6 \%$ of the respondents said they did suffer from Hepatitis A, B, and $\mathrm{C}$ respectively.

Table 7: Summary of Diseases Report from Health Survey in the

\begin{tabular}{ll}
\multicolumn{2}{c}{ area of } \\
\hline study \\
\hline Demographic & Outcomes \\
Male (adult) & 260 \\
Female (adult) & 310 \\
Male (children) & 250 \\
Female (children) & 180 \\
Health Based & \\
Hepatitis-based (\%) & \\
Hepaatitis A & 10 \\
Hepatitis B & 7 \\
Hepatitis C & 6 \\
Cholera & 6 \\
Typhoid & 25 \\
Diarrhea & 18 \\
Anemia & 12 \\
Dysentry & 26 \\
Cancer & 1 \\
Gastroenteritis & 16 \\
Insomnia & 28 \\
Poor appetite & 21 \\
Constipation & 24 \\
Vomiting & 15 \\
Malaria & 22 \\
Pneumonia & 3 \\
Skin diseases & 2 \\
Nausea & 2 \\
\hline
\end{tabular}

The high percetangtes reported for typhoid (25\%), diarrhea(18\%), dysentry(26\%) and constispation (24\%) can be linked to the bacterial contamination of groundwater in the area of study (Khan et al., 2013). Gastroenteritis $(16 \%)$ can be linked to $\mathrm{Pb}$ and $\mathrm{Cd}$ contamination (Dahunsi et al., 2014)). Health problems such as anemia, cancer, pneumonia, skin diseases and nausea, though reported by less than 3 $\%$ of the respondents; can be linked with the ingestion of high concentrations of lead and cadmium, which were detected in the study area as contaminants in the drinking water (Dahunsi et al., 2014).

Conclusion: The correlation analysis showed that the main cations and anions responsible for the groundwater TDS were $\mathrm{Na}, \mathrm{Mg}, \mathrm{Ca}$, and $\mathrm{K}$, and $\mathrm{SO}_{4}{ }^{2-}$ and $\mathrm{Cl}^{-}$respectively. Samples from the HDW had higher coliform bacteria count values. While a large percentage of the residents did not have enough information with regards to household water treatment, diseases reported by respondents were observed to have close link with the contaminants revealed by the study. The agencies of water resources management in Delta State should endeavor to provide clean water for the residents of the study area. Household water treatment is also 
recommended to prevent any possible outbreak of water borne diseases.

Acknowledgements: The financial assistance of the Academic Research and Entrepreneurship Development Initiative, Asaba and its Vice-President (Samuel Ilabor) technical support, are well acknowledged. My then final year undergraduate project students are also appreciated for their support during data collection.

\section{REFERENCES}

Adejuwon, A O; Bisi-John, M A; Agboola, O A; Fadeyi, B O; Adejuwon, A O (2011). Antibiotics sensitivity patterns of Escherichia coli and Aerobacter aerogenes isolated from well water in Ile-Ife, Nigeria. Interna. J. Med. Med. Sci. 3(5):155-160

Agbabiaka, T O; Sule, I O (2010). Bacteriological assessment of selected borehole water samples in Ilorin Metropolis. IJABR 2(2): 31-37

Akri, B (2015). Hydrochemical processes regulating groundwater quality in the coastal plain of $\mathrm{Al}$ Musanaah, Sultanate of Oman. J. Afri. Earth Sci. 106: 87-98

APHA (1992). "Standard Methods for Examination of Water and Waste-water"; 18th Edition, Washington DC: American Public Health Association

APHA (2012). "Standard Methods for Examination of Water and Waste-water"; 22nd Edition, Washington DC: American Public Health Association

Dahunsi, S O; Owamah, H I; Ayandiran, T A; Oranusi, U S (2014). Drinking water quality and public health of selected communities in South Western Nigeria. Wat. Qual. Expo. Heal. 6:143-153

Fay, M; Limi, A; Perrissin-Fabert, B (2010). Financing greener and climate-resilient infrastructure in developing countries: challenges and opportunities. EIB 15:34-58

Jacinta, A N; Adebayo, I A (2015). Determination of coliforms in different sources of drinking water in Gwagwalada Abuja. Report and Opinion 7(1):1-6

Khan, S; Shahnaz, M; Jehai, N; Rehman, S; Shah, M T; Din, S (2013). Drinking water quality and human health risk in Charsadda district, Pakistan. J. Cleaner Prod. 60:93-101

Mackie, R I; Koike, S; Krapac, I; Chee-Sanford, J; Maxwell, S; Aminov, R I (2006). Tetracycline residues and tetracycline resistance genes in groundwater impacted by swine production facilities. Animal Biotech. 17:157-176
Mkwate , R C; Chidya, RCG; Wanda, E M M(2017). Assessment of drinking water quality and rural household water treatment in Balaka District, Malawi. Phys. Chem. Earth 100:353-362

Masoud, AA; Meswara, EA; El Bouraie, MM; Kamh, SZ (2018). Monitoring and assessment of the groundwater quality in wadi Al-Arish downstream area, North Sinai (Egypt). J. Afri. Earth Sci. 140: 225240 .

Mwabi, J K; Mamba, B B; Momba, M N B(2012). Removal of Escherichia coli and faecal coliforms from surface water and groundwater by household water treatment devices/systems: a sustainable solution for improving water quality in rural communities of the Southern African Development Community (SADC) Region. Int. J. Environ. Res. Pub.Heal. 9:139-170

Owamah, I H; Asiagwu, A K; Egboh, SHO; Phil-Usiayo, S (2013). Drinking water quality at Isoko North communities of the Niger Delta Region, Nigeria.Toxi. Environ. Chem. 95(7):1116-1128

Oyegoke, S O; Adeyemi, A O; Sojobi, A O (2012). The challenges of water supply for a megacity: a case study of Lagos Metropolis. Inter. J. Sci. Eng. Res. 3(2): $1-10$

Shakerkhatibi, M; Mosaferia, M; Pourakbarf, M; Ahmadnejad, M; Safavi, N; Banitorab, N. (2019). Comprehensive investigation of groundwater quality in the north-west of Iran: Physicochemical and heavy metal analysis.Groundwater Sust. Dev. 8: 156-168

Sojobi, S O (2016). Evaluation of groundwater quality in a rural community in North Central of Nigeria. Environ. Monit. Assess. 188:192-201

SON (2007). Standrad Organization of Nigeria (SON). Nigerian Standard for Drinking Water Quality, Nigeria, NIS 554: 2007

Skrzypek, G; Dogramaci, S; Grierson, P F (2013). Geochemical and hydrological processes controlling groundwater salinity of a large inland wetland of northwest Australia. Chem. Geol., 357: 164-177

Vorosmarty, CJ; McIntyre, P B; Gessner, M O (2010). Rivers in global crisis: water insecurity for humans and biodiversity. Nature, 467:555-561

WHO (2006). "Guidelines for Drinking Water Quality”, $3^{\text {rd }}$ Edition, Vol. I Recommendations. First addendum to $3^{\text {rd }}$ Edition, Geneva: World Health Organization

World Bank (2011). Framework for strong, sustainable and balanced growth. Rebalancing growth, and development. Washington DC, World Bank, 